\title{
Seasonal Incidence and Management of Cabbage White Butterfly, Pieris brassicae (Linnaeus) (Lepidoptera: Pieridae) on Cabbage Crop
}

\author{
Sonika Sharma*, Hafeez Ahmad, Suheel Ahmad Ganai, Devinder Sharma, \\ Thanlass Norboo, Nadeya Khaliq and Mahesh Kumar
}

\author{
Block No. 6, Division of Entomology, FoA, Main Campus, SKUAST-J, \\ Chatha, Jammu-180 009, J\&K, India \\ *Corresponding author
}

\section{A B S T R A C T}

\begin{tabular}{|c|c|}
\hline & $\begin{array}{l}\text { Experiments conducted on the seasonal incidence of Pieris brassicae L. during 2014-2015 } \\
\text { and 2015- } 2016 \text { at the University Farm of Sher-e-Kashmir University of Agricultural }\end{array}$ \\
\hline Keywords & $\begin{array}{l}\text { Sciences and Technology- Jammu revealed that } P \text {. brassicae were first observed in the } 43^{\text {rd }} \\
\text { standard week }\left(1.33 \text { larvae plant }{ }^{-1}\right) \text { and lowest population of } 0.12 \text { larvae per plant during }\end{array}$ \\
\hline $\begin{array}{l}\text { Pieris brassicae, } \\
\text { Seasonal incidence, } \\
\text { Cabbage, Efficacy, } \\
\text { Insect growth } \\
\text { regulators. }\end{array}$ & $\begin{array}{l}\text { the } 15^{\text {th }} \text { standard week. The } P \text {. brassicae population was maximum }\left(5.74 \text { larvae plant }{ }^{-1}\right) \text { in } \\
7^{\text {th }} \text { standard week, respectively. The maximum and minimum temperature showed } \\
\text { significant negative correlation with } r \text { values }\left(r=-0.545^{* *} \text { and } r=-0.631^{* *}\right) \text {, while } \\
\text { relative humidity (morning) had a positive and highly significant effect with } \mathrm{r} \text { value }(\mathrm{r}= \\
\left.0.622^{* *}\right) \text { impact on larval population. Whereas relative humidity (evening) and rainfall }\end{array}$ \\
\hline Article Info & had no significant effect with $r$ value $(r=0.162$ and $r=-0.205)$ on the larval population. \\
\hline $\begin{array}{l}\text { Accepted: } \\
\text { 15 September } 2017 \\
\text { Available Online: } \\
10 \text { November } 2017\end{array}$ & $\begin{array}{l}\text { towards larval population. The relative efficacy of insect growth regulators against the } \\
\text { cabbage white butterfly, } P \text {. brassicae showed that fenvalerate had higher efficacy against } \\
P \text {. brassicae in reducing pest population. Mean population of } P \text {. brassicae after two sprays }\end{array}$ \\
\hline & $\begin{array}{l}0.006 \% \text { and novaluran } 0.100 \% \text { which were at par. chlorfenapyr } 0.150 \% \text { was found to be } \\
\text { least effective against P. xylostella. }\end{array}$ \\
\hline
\end{tabular}

\section{Introduction}

The cabbage white butterfly, Pieris brassicae (Linnaeus) (Lepidoptera: Pieridae), is a serious pest of cauliflower and cabbage in our region (Shankar et al., 2016) as well as world (Hasan, 2008). A single larva can consume about 74 to $80 \mathrm{~cm}^{2}$ leaf area (Younas et al., 2004). In cruciferous vegetables, this pest alone causes 40 per cent yield loss annually in India (Hasan and Ansari, 2010). As a result of feeding, the plants either fail to form compact cabbage heads or produce deformed heads
(Uddin et al., 2007). The severity of the incidence of insect pests is greatly influenced by the prevailing climatic conditions (Meena et al., 2013). At present, the information regarding the influence of weather parameters on the incidence of this pest and bioefficacy of insect growth regulators under field condition for their comparative efficacy against Pieris brassicae is very less. Therefore, keeping in view the economic importance of the crop and the magnitude of 
the damage caused by the insect, the present study has been proposed.

\section{Materials and Methods}

The experiment was conducted at University Farm SKUAST-Jammu, Main Campus Chatha, and Jammu during 2014-15 and 2015-16. Cabbage (Variety Pride of India) were sown in raised nursery beds in lines with $7 \mathrm{~cm}$ distance and $1 \mathrm{~cm}$ deep, which were covered with a mixture of soil and well decomposed farmyard manure. The bed was covered with paddy straw which was removed after germination of seeds. The seedlings were ready for transplanting after 30 days and were transplanted in plot size of $4 \times 3 \mathrm{~m}^{2}$ with row to row and plant to plant distance of 60 and $45 \mathrm{~cm}$. respectively. Observations on the seasonal incidence of $P$. brassicae were recorded on 10 randomly selected plants. The experiment was laid out in randomized block design (RBD) with four replications. For the $P$. brassicae management, a trial was laid out in the randomized block design with four replications. Five insecticidal formulations including control were tested as given below. Observations on the $P$. brassicae population from the selected plants were recorded before and after 1, 3, 7 and 15 days of spray. Data thus obtained were analysed statistically and the efficacy of the insecticides were worked out.

T1- Novaluron 10EC @ 0.10\%

T2-Lufenuron5 EC@0.006\%

T3- Fenvalerate 20 ES @ 0.004\%

T4- Chlorflenapyr 10 SC @ 0.15\%

T5- Control

\section{Results and Discussion}

\section{Seasonal Incidence of $P$. brassicae on cabbage}

Pooled data for the both years (Table 1 and Fig. 1) revealed that larvae (1.33 larvae plant $^{-1}$ ) was observed right from $43^{\text {rd }}$ standard week, when the mean maximum, minimum temperature, mean relative humidity and rainfall were 27.10 and $13.00^{\circ} \mathrm{C}, 84.00$ and 57.50 per cent and $7.20 \mathrm{~mm}$, respectively. Larval population reached it's peaked during $7^{\text {th }}$ standard week with (5.74 larvae plant ${ }^{-1}$ ) when the mean maximum, minimum temperature, mean relative humidity and rainfall were 22.80 and $10.30^{\circ} \mathrm{C}, 87.00$ and 49.50 per cent and $2.90 \mathrm{~mm}$, respectively. The larval population declined and reached to minimum of 0.68 larvae plant $^{-1}$ during $16^{\text {th }}$ standard week. The present finding are in agreement with the findings of Sharma et al., (2005) who found that the larvae first appeared on cauliflower in the first week of November, and the population peaked during the fourth week of January 2005, and remained active up to April. In the present investigation, the number of larvae per plant ranged from 0.56-12.03. Ahmad et al., (2007) also recorded the larvae first appeared on cabbage in $43^{\text {rd }}$ standard week (8.60 larvae plant $^{-1}$ ) and the population peaked to 58.10 larvae plant ${ }^{-1}$ during the $50^{\text {th }}$ standard week, and remained active up to $7^{\text {th }}$ standard week and Sharmila et al., (2015) revealed that the larvae first appeared on cabbage in first week of November (7.40 larvae plant ${ }^{-1}$ ) and the population peaked to 23.22 larvae plant $^{-1}$ during $3^{\text {rd }}$ week of march. The number of larvae per plant ranged from 0.56-12.03 larvae plant $^{-1}$ and remained active up to ending March.

Pooled data for both the years (Table 2) revealed that mean maximum temperature and relatively humidity (morning) had negative but highly significant effect on larval population with ' $r$ ' values $(r=-0.545$ and $r=-$ 0.631 ) and relative humidity morning had positive but highly significant effect on larval population with ' $r$ ' value $(r=0.622)$. On the other hand mean relative humidity had positive effect on larval population with ' $r$ ' value $(r=0.162)$ and mean rainfall had 
negative effect on larval population with ' $r$ ' value ( $r=-0.205)$. Regression studies for both the years revealed that weather factors had 61.00 and 48.30 per cent effect and pooled data had 45.30 per cent influenced on larval population.

The present finding are in finding are in conformity with Sharma et al., (2005) who observed that weather parameters, significantly correlated and positively with the temperature (maximum) relative humidity (morning and evening) and rainfall. However, maximum and minimum temperature had negative effect on their population, as the correlates were highly significant and negative. However, the present findings are in contradiction with those of Khan and Talukder (2017) who found that the population of $P$. brassicae was positively correlated with maximum and minimum temperatures while negative correlation with maximum relative humidity and a strong negative correlation minimum relative humidity.

Efficacy of the insecticides revealed that all the treatments at $1,3,7$ and 15 days after spray were superior to control (Table 3 and Fig. 2). The pooled data during 2014-15 and 2015-16 (First spray) revealed that there was no significant difference between the treatments one day before spray. The observations recorded on $1^{\text {st }}$ day after spray revealed that all the treatments proved significantly superior over control. Fenvalerate 20 ES (10.13 larvae/ plant) was found to be most effective followed by lufenuron 5 EC (11.88 larvae/ plant), novaluron $10 \mathrm{EC}$ (14.13larvae/ plant) were statistically at par with each other whereas chlorfenapyr 10 SC (15.38 larvae /plant) was found to be least effective. After 3days of application all the treatments proved significantly superior over control. Fenvalerate 20 ES (5.63 larvae/ plant) was found to be most effective treatment in reducing the larval population. The treatments viz., lufenuron 5 EC (7.63 larvae/ plant), novaluron 10 EC (9.38 larvae/ plant) were statistically at par with each other whereas chlorfenapyr10 SC (12.88 larvae /plant) was found to be least effective. The observations recorded on 7th day after spray revealed that all the treatments proved significantly superior over control.

Fenvalerate 20 ES (2.50 larvae/ plant) was found to be most effective treatment in reducing the larval population. The treatments viz., lufenuron 5 EC (4.38 larvae/ plant), novaluron $10 \mathrm{EC}$ (6.38 larvae/ plant) were statistically at par with each other whereas chlorfenapyr10 SC (9.50 larvae/plant) was found to be least effective. On $15^{\text {th }}$ day after spray revealed that all the treatments proved significantly superior over control. Fenvalerate 20 ES (3.00 larvae/ plant) was found to be most effective treatment in reducing the larval population. The treatments viz., lufenuron 5 EC (5.75 larvae/ plant), novaluron 10 EC (7.13 larvae/ plant) were statistically at par with each other whereas chlorfenapyr10 SC (10.50 larvae /plant) was found to be least effective.

Second spray revealed (Table 3 and Fig. 2) that there was no significant difference between the treatments one day before spray. The observations recorded on $1^{\text {st }}$ day after spray revealed that all the treatments proved significantly superior over control. Fenvalerate 20 ES (5.25 larvae/ plant) was found to be most effective treatment in reducing the larval population. The treatments viz., lufenuron 5 EC (8.88 larvae/ plant), novaluron 10 EC (9.75 larvae/ plant) were statistically at par with each other whereas chlorfenapyr10 SC (12.50 larvae /plant) was found to be least effective. After $3{ }^{\text {rd }}$ day after of application, all the treatments proved significantly superior over control. 
Table.1 Seasonal incidence of $P$. brassicae on cabbage (pooled)

\begin{tabular}{|c|c|c|c|c|c|c|}
\hline \multirow{3}{*}{ Standard week } & \multirow{3}{*}{ *Larval population / plant } & \multicolumn{5}{|c|}{ Metrological Parameters } \\
\hline & & \multicolumn{2}{|c|}{ Temperature $\left({ }^{\circ} \mathrm{C}\right)$} & \multicolumn{2}{|c|}{ Relative Humidity (\%) } & \multirow{2}{*}{ Rainfall (mm) } \\
\hline & & Maximum & Minimum & Morning & Evening & \\
\hline 43 & 1.33 & 27.10 & 13.00 & 84.00 & 57.50 & 7.20 \\
\hline 44 & 1.55 & 26.80 & 12.70 & 89.00 & 64.00 & 1.50 \\
\hline 45 & 2.12 & 26.10 & 8.40 & 88.00 & 65.00 & 0.40 \\
\hline 46 & 2.64 & 24.70 & 7.30 & 88.50 & 45.50 & 0.00 \\
\hline 47 & 3.36 & 24.80 & 8.10 & 90.00 & 43.50 & 0.00 \\
\hline 48 & 3.67 & 24.90 & 6.00 & 91.00 & 44.00 & 0.00 \\
\hline 49 & 3.53 & 19.80 & 5.40 & 93.00 & 50.00 & 0.00 \\
\hline 50 & 3.03 & 12.90 & 5.10 & 95.50 & 73.00 & 14.20 \\
\hline 51 & 2.91 & 15.80 & 3.30 & 93.50 & 59.50 & 0.00 \\
\hline 52 & 2.58 & 19.70 & 4.70 & 91.00 & 49.50 & 0.00 \\
\hline 1 & 2.52 & 11.80 & 5.80 & 93.50 & 72.00 & 0.90 \\
\hline 2 & 3.44 & 14.70 & 6.00 & 86.50 & 54.00 & 0.45 \\
\hline 3 & 4.27 & 18.80 & 6.50 & 93.00 & 70.50 & 0.80 \\
\hline 4 & 5.40 & 17.00 & 4.60 & 95.00 & 64.50 & 0.00 \\
\hline 5 & 5.56 & 18.80 & 6.00 & 93.00 & 62.00 & 9.15 \\
\hline 6 & 5.70 & 21.40 & 6.40 & 87.50 & 47.00 & 1.40 \\
\hline 7 & 5.74 & 22.60 & 10.30 & 87.00 & 49.50 & 2.90 \\
\hline 8 & 5.37 & 22.80 & 12.40 & 87.50 & 60.00 & 31.65 \\
\hline 9 & 4.51 & 19.50 & 9.70 & 87.00 & 62.00 & 58.30 \\
\hline 10 & 3.51 & 20.60 & 9.70 & 86.00 & 57.50 & 14.45 \\
\hline 11 & 2.59 & 22.60 & 10.10 & 88.50 & 66.00 & 86.70 \\
\hline 12 & 1.70 & 29.10 & 13.50 & 82.00 & 49.50 & 0.10 \\
\hline 13 & 0.61 & 26.10 & 15.50 & 84.10 & 59.80 & 49.80 \\
\hline 14 & 0.24 & 25.00 & 15.10 & 79.50 & 53.50 & 56.70 \\
\hline 15 & 0.68 & 31.40 & 16.80 & 75.45 & 39.60 & 0.80 \\
\hline 16 & 0.680 .12 & 32.10 & 17.80 & 77.00 & 48.00 & 30.00 \\
\hline Range & $0.12-5.74$ & 11.80-32.10 & $3.30-17.80$ & $75.45-95.50$ & 39.6-73.00 & \begin{tabular}{|l|}
$0.00-86.70$ \\
\end{tabular} \\
\hline Mean & 3.03 & 22.19 & 9.24 & 87.93 & 56.42 & 14.13 \\
\hline $\operatorname{S.Em}( \pm)$ & 1.71 & 5.23 & 4.12 & 5.26 & 9.35 & 23.56 \\
\hline
\end{tabular}


Table.2 Correlation coefficients and regression model between mean larval population of P. brassicae and abiotic factors

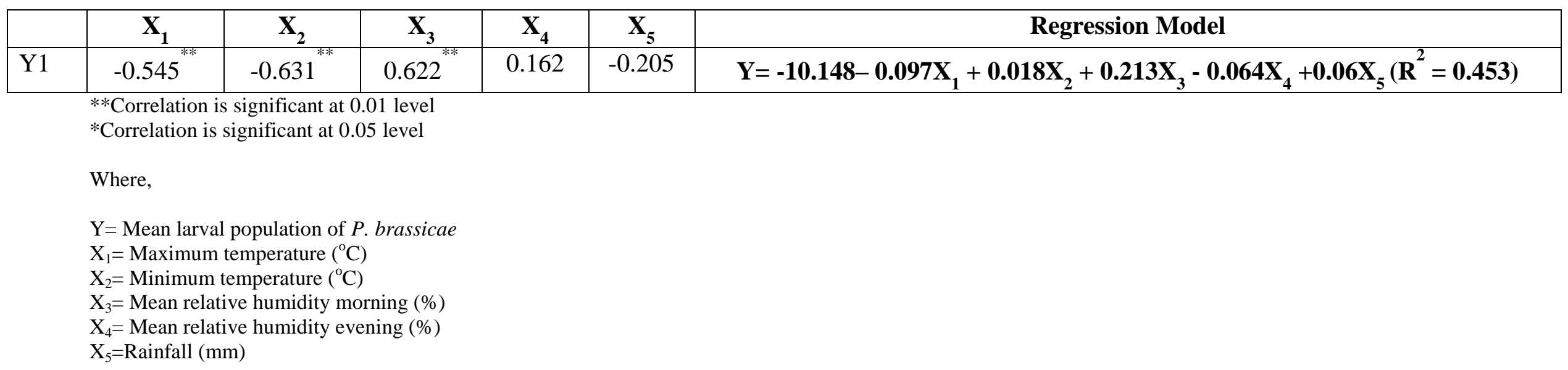

Table.3 Efficacy of insecticides against $P$. brassicae, population on cabbage (pooled)

\begin{tabular}{|c|c|c|c|c|c|c|c|c|c|c|c|}
\hline \multirow[t]{3}{*}{ Treatments } & \multirow{3}{*}{$\begin{array}{c}\text { Concentratio } \\
\text { n } \\
(\%)\end{array}$} & \multicolumn{10}{|c|}{ Larval population of Pieris brassicae /plant } \\
\hline & & \multicolumn{5}{|c|}{ First spray } & \multicolumn{5}{|c|}{ Second spray } \\
\hline & & $1 \mathrm{DBS}$ & 1DAS & 3DAS & 7DAS & 15DAS & $1 \mathrm{DBS}$ & 1DAS & 3DAS & 7DAS & 15DAS \\
\hline Novaluron $10 \mathrm{EC}$ & $0.10 \%$ & $\begin{array}{l}16.50 \\
(0.41) \\
\end{array}$ & $\begin{array}{r}14.13 \\
(0.38) \\
\end{array}$ & $\begin{array}{l}9.38 \\
(0.43) \\
\end{array}$ & $\begin{array}{c}6.38 \\
(0.59) \\
\end{array}$ & $\begin{array}{c}7.13 \\
(0.55) \\
\end{array}$ & $\begin{array}{l}15.88 \\
(0.43) \\
\end{array}$ & $\begin{array}{c}9.75 \\
(0.32) \\
\end{array}$ & $\begin{array}{c}5.88 \\
(0.38)\end{array}$ & $\begin{array}{c}2.50 \\
(0.20)\end{array}$ & $\begin{array}{c}3.50 \\
(0.35)\end{array}$ \\
\hline Lufenuron $5 \mathrm{EC}$ & $0.006 \%$ & $\begin{array}{l}16.88 \\
(0.43) \\
\end{array}$ & $\begin{array}{l}11.88 \\
(0.55)\end{array}$ & $\begin{array}{c}7.63 \\
(0.32) \\
\end{array}$ & $\begin{array}{c}4.38 \\
(0.43) \\
\end{array}$ & $\begin{array}{c}5.75 \\
(0.60) \\
\end{array}$ & $\begin{array}{r}16.00 \\
(0.35) \\
\end{array}$ & $\begin{array}{c}8.88 \\
(0.43) \\
\end{array}$ & $\begin{array}{c}4.63 \\
(0.13) \\
\end{array}$ & $\begin{array}{c}1.75 \\
(0.32) \\
\end{array}$ & $\begin{array}{r}2.50 \\
(0.74) \\
\end{array}$ \\
\hline Fenvalerate $20 \mathrm{ES}$ & $0.004 \%$ & $\begin{array}{l}16.25 \\
(0.25)\end{array}$ & $\begin{array}{l}10.13 \\
(0.55)\end{array}$ & $\begin{array}{c}5.63 \\
(0.83)\end{array}$ & $\begin{array}{c}2.50 \\
(0.46)\end{array}$ & $\begin{array}{c}3.00 \\
(0.55)\end{array}$ & $\begin{array}{l}15.13 \\
(0.43)\end{array}$ & $\begin{array}{c}5.25 \\
(0.32)\end{array}$ & $\begin{array}{c}1.88 \\
(0.38)\end{array}$ & $\begin{array}{c}0.38 \\
(0.24)\end{array}$ & $\begin{array}{c}1.00 \\
(0.20)\end{array}$ \\
\hline $\begin{array}{l}\text { Chlorflenapyr } 10 \\
\text { SC }\end{array}$ & $0.15 \%$ & $\begin{array}{l}16.88 \\
(0.38)\end{array}$ & $\begin{array}{l}15.38 \\
(0.24)\end{array}$ & $\begin{array}{l}12.88 \\
(0.72)\end{array}$ & $\begin{array}{c}9.50 \\
(1.40)\end{array}$ & $\begin{array}{l}10.50 \\
(0.84)\end{array}$ & $\begin{array}{l}16.25 \\
(0.60)\end{array}$ & $\begin{array}{l}12.50 \\
(0.20)\end{array}$ & $\begin{array}{c}8.38 \\
(0.24)\end{array}$ & $\begin{array}{c}5.75 \\
(0.14)\end{array}$ & $\begin{array}{c}6.75 \\
(0.14)\end{array}$ \\
\hline Control & - & $\begin{array}{l}16.25 \\
(0.75)\end{array}$ & $\begin{array}{l}16.00 \\
(1.43)\end{array}$ & $\begin{array}{l}17.00 \\
(2.23)\end{array}$ & $\begin{array}{l}18.13 \\
(2.01)\end{array}$ & $\begin{array}{l}20.75 \\
(0.52) \\
\end{array}$ & $\begin{array}{l}16.38 \\
(0.52)\end{array}$ & $\begin{array}{l}17.75 \\
(0.77) \\
\end{array}$ & $\begin{array}{l}18.75 \\
(0.14)\end{array}$ & $\begin{array}{l}19.00 \\
(0.20)\end{array}$ & $\begin{array}{l}18.75 \\
(1.23)\end{array}$ \\
\hline $\mathrm{CD}(\mathrm{p} \leq 0.05)$ & - & NS & 2.63 & 3.92 & 4.02 & 1.67 & NS & 1.47 & 0.88 & $\mathbf{0 . 7 0}$ & 1.82 \\
\hline SE(m) & - & 0.44 & 0.84 & 1.26 & 1.29 & 0.54 & 0.49 & 0.47 & 0.29 & $\mathbf{0 . 2 3}$ & 0.58 \\
\hline
\end{tabular}

*DBS - Days before Spray, ${ }^{\text {DAS }}$ - Days after Spray, Figures in parenthesis are square $\sqrt{\mathrm{x}}+0.5$ transformed values 
Fig.1 Seasonal incidence of larval population of $P$. brassicae on Cabbage (pooled)

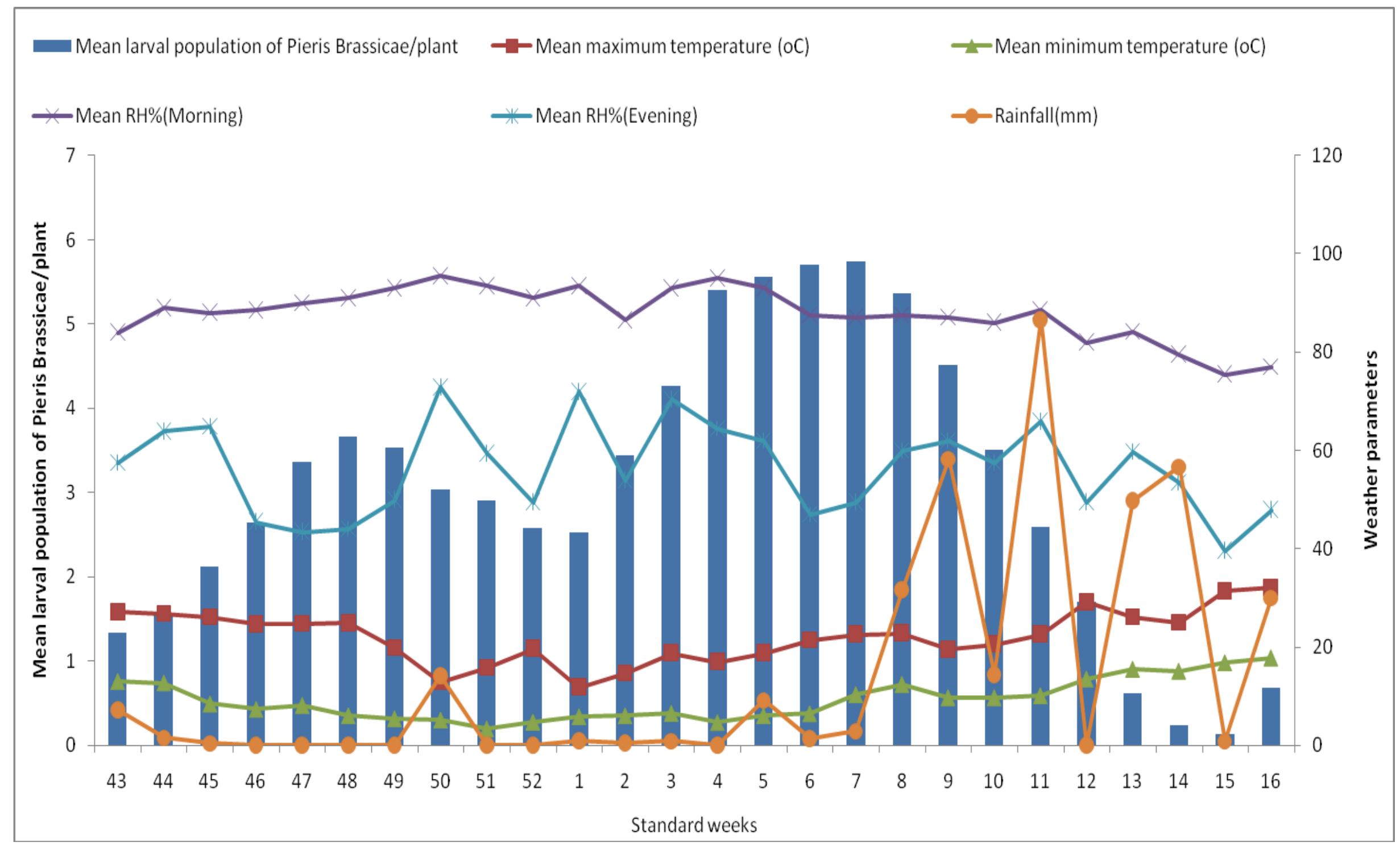


Int.J.Curr.Microbiol.App.Sci (2017) 6(11): 1913-1921

Fig.2 Efficacy of different insecticides against $P$. brassicae (pooled)

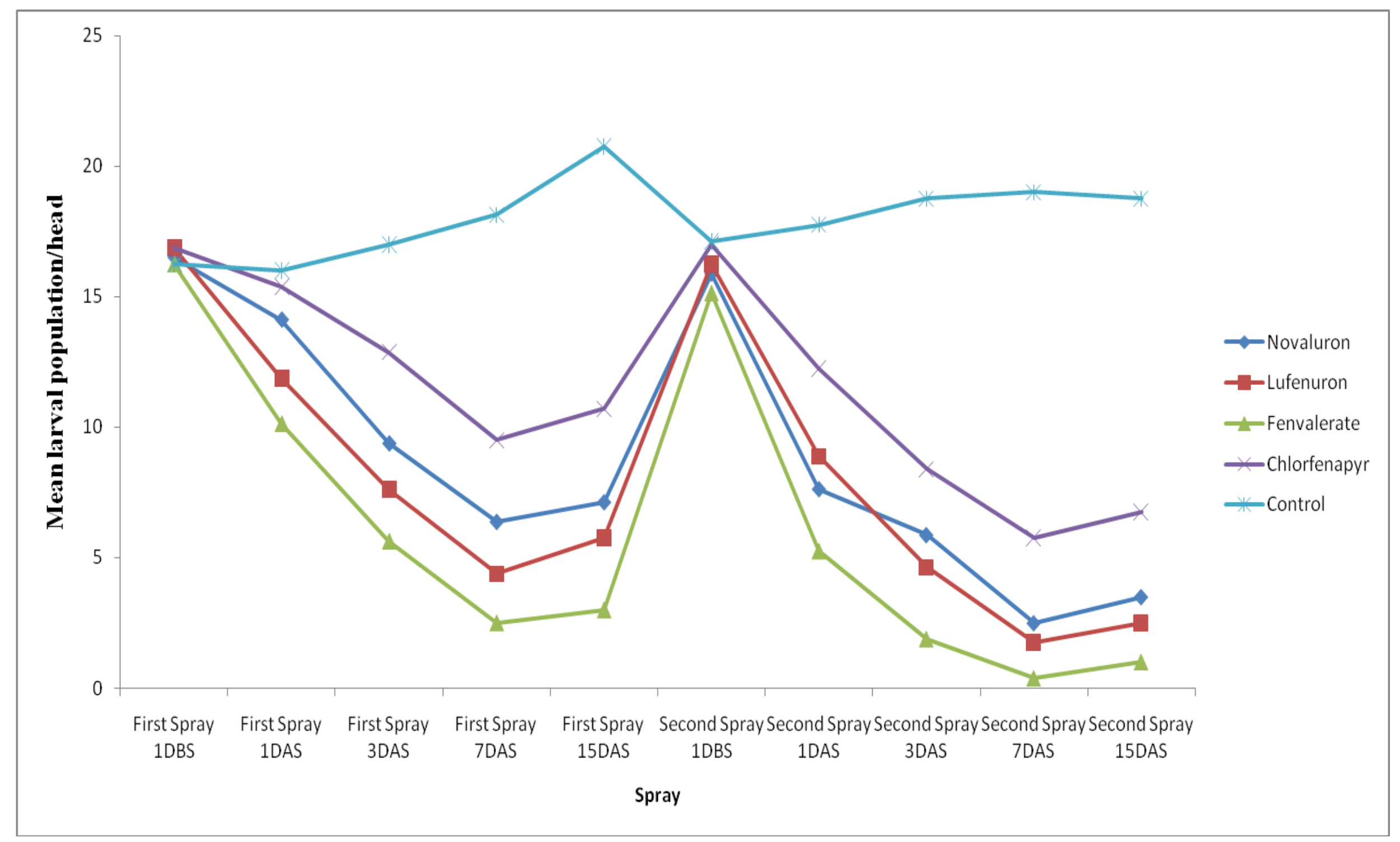


Fenvalerate 20 ES (1.88 larvae/ plant) was found to be most effective followed by lufenuron 5 EC (4.63 larvae/ plant), novaluron 10 EC (5.88 larvae/ plant) were statistically at par with each other whereas and chlorfenapyr10 SC (8.38 larvae /plant) was found to be least effective. On $7^{\text {th }}$ day after spray revealed that all the treatments proved significantly superior over control. Fenvalerate 20 ES (0.38 larvae/ plant) was found to be most effective followed by lufenuron 5 EC (1.75 larvae/ plant), novaluron 10 EC (2.50 larvae/ plant) were statistically at par with each other whereas and chlorfenapyr10 SC (5.75 larvae /plant) was found to be least effective. On $15^{\text {th }}$ day after spray revealed that all the treatments proved significantly superior over control. Fenvalerate 20 ES (1.00 larvae/ plant) was found to be most effective followed by lufenuron 5 EC (2.50 larvae/ plant), novaluron 10 EC (3.50 larvae/ plant) were statistically at par with each other whereas chlorfenapyr $10 \mathrm{SC}$ (6.75larvae /plant) was found to be least effective. The present investigations were in agreement with those of Thakur, (1996) and Thakur and Deka, (1997a) evaluated for control of $P$. brassicae in cabbage with eleven insecticides, Overall, fenvalerate gave virtually $100 \%$ control of $P$. brassicae, followed by deltamethrin (97.3\%), cypermethrin (96.8\%), malathion (96.08\%) and fenitrothion (93.3\%). Similarly, these findings are corroborates with those of Someya et al., (2007). The present results of chlorfenapyr are in line with those of Shashi Bhushan et al., (2010) who reported the effectiveness of chlorfenapyr against $S$. litura Fab.

\section{Acknowledgements}

The authors are thankful to the Professor and Head, Division of entomology, SKUASTJammu for providing facilities to carry out this work.

\section{References}

Ahmad, H., Shankar, U. and Monobrullah, M. 2007. Incidence of cabbage butterfly, Pieris brassicae Linn. across different sowing dates on cabbage. Indian J. Entomol., 69(3); 307.

Hasan, F. and Ansari, M.S. 2010. Effect of different cole crops on the biological parameters of Pieris brassicae (L.) (Lepidoptera: Pieridae) under laboratory conditions. J. Crop Sci. Biotech., 13(3): 195-202.

Hasan, W., Gupta, A.K. and Singh, C.P. 2008. Biology of cabbage butterfly, Pieris brassicae (L.) (Lepidoptera: Pieridae) on cabbage and Indian mustard. $J$. Oilseeds Res., 25: 104-5.

Khan, M.M.H. and Talukder, S. 2017. Influence of weather factors on the abundance and population dynamics of Spodoptera litura F. and Pieris brassicae $L$. on cabbage. J. Agric., 15(1): 13-21.

Meena, R.S., Ameta, O.P. and Meena, B.L. 2013. Population dynamics of sucking pests and their correlation with weather parameter in chili, Capsicum annum L. crop. The Bioscan, 8(1): 177-180.

Shankar. U., Kumar. D., Singh. S.K. and Gupta, S. 2016. Pest complex of cole crops and their management. Technical Bulletin No. 1, SKUAST-Jammu, p.14

Sharma, D., Abrol, D.P. and Bhagat, R.M. 2005. Seasonal incidence of Brevicoryne brassicae L. and Pieris brassicae L. on cauliflower seed crop in Jammu sub tropics. SKUAST J. Res., 4: 214-218.

Sharmila, M., Devjani, P. and Singh, N.I. 2015. Field density and management of Pieris brassicae under the climatic conditions of the valley region of Manipur. Internat. J. Trop. Agric., 33(2): 1697-1701.

Shashi Bhushan, V., Ramesh Babu, V., 
Dharmareddy K. and Umamaheswari, T. 2010. Efficacy of certain insecticides against Spodoptera litura Fab. on potato. Karnataka J. Agric. Sci., 23: 195-96.

Someya, H., Takano, S., Tatematsu, Y., Hayase, T., Kawabata, J. and Imamura, T. 2007. Effects of some insecticides on mortality of Pieris brassicae (Linnaeus) (Lepidoptera: Pieridae). Res. Bull. Plant Prot. Ser. Japan, 43: 33-35.

Thakur, N.S.A. 1996. Relationship of cabbage butterfly larval (Pieris brassicae Linn.) population on the marketable yield of cabbage. J. Hill Res., 9(2): 356-358.

Thakur, N.S.A. and Deka, T.C. 1997. Bioefficacy and economics of different insecticides against Pieris brassicae (L.) on cabbage in midhills of North-
East India. Indian J. Plant Prot., 25(2): 109-114.

Uddin, M.N., Hoque, M.M., Hossain, S.M.M., Alam, S.N., Mollik, A.K.M.S.R., Khorsheduzzaman, A.K.M., Alam, S., Rahman, M.M., Karim, A.N.M.R., Rajotte, E.G. and Luther, G.C. 2007. IPM approach for controlling two lepidopteran pests of cabbage in Bangladesh. Bangladesh J. Entomol., 17(1): 19-29

Younas, M., Naeem, M., Raqib, A. and Masud, S. 2004. Population dynamics of cabbage butterfly (Pieris brassicae) and cabbage aphids (Brevicoryne brassicae) on five cultivars of cauliflower at Peshawar. Asian J. Plant Sci., 3: 391-393.

\section{How to cite this article:}

Sonika Sharma, Hafeez Ahmad, Suheel Ahmad Ganai, Devinder Sharma, Thanlass Norboo, Nadeya Khaliq and Mahesh Kumar. 2017. Seasonal Incidence and Management of Cabbage White Butterfly, Pieris brassicae (Linnaeus) (Lepidoptera: Pieridae) on Cabbage Crop. Int.J.Curr.Microbiol.App.Sci. 6(11): 1913-1921. doi: https://doi.org/10.20546/ijcmas.2017.611.227 